\title{
The Influence of Welding Ampere Range to ST-40 Shear Strength with Butt Joint
}

\author{
Rudi Winarno ${ }^{a}$, Daryonob, M. Jufric \\ a, b, cMechanical Engineering, University of Muhammadiyah Malang \\ Jl. Raya Tlogomas No. 246 Telp. (0341) 464318-128 Fax. (0341) 460782 Malang \\ Email: Rudiwinarno94@gmail.com, daryono@umm.ac.id, jufri@umm.ac.id
}

\begin{abstract}
This experiment was conducted on the influence of welding process with ampere range variation and weld joints toward ST-40 shear strength. Furthermore, welded specimen is tested with tensile test. Method of this experiment is testing shear strength by using tensile testing machine where each five-specimens were previously welded by ampere range of $80 \mathrm{~A}, 90 \mathrm{~A}$, and $100 \mathrm{~A}$. Shear results show the highest shear strength is on 128.4916 $\mathrm{N} / \mathrm{mm}^{2}$ with 80 -ampere range on specimen no. 5, while on 90-ampere range variation the highest shear strength is on $124.7528 \mathrm{~N} / \mathrm{mm}^{2}$, the specimen no. 5. Meanwhile, on 100-ampere range variation, the highest shear strength is on $120.1484 \mathrm{~N} / \mathrm{mm}^{2}$, the specimen no. 4. The higher ampere (I) used, the higher heat $(Q)$ resulted. When the heat increases, the welding electrode is perfectly fused. It makes good welding result achieved. The more strength on welding result, the higher shear strength $(T)$ achieved. On the other hand, the higher ampere range on welding process results higher shear strength.
\end{abstract}

Keywords: welding; ampere range; shear strength

\section{INTRODUCTION}

Many factors can influence welding result [1], namely method and procedure of welding, equipment, materials needed, electrode, ampere range applied, seam distance, and seam angle applied [2][3]. Ampere range and seam angle are considered to be experimented. Variation on ampere range and seam type for welding are determined to achieve stronger and better welding result [4].

Testing on welding area is divided into two, destructive and non-destructive tests [5]. Destructive test is conducting by giving tensile test to welded material. Tensile test is method aimed to examine material strength by giving linear load. By pulling a material, its reaction to pulling force would be recognized. Moreover, it would show its elongation during it is pulled. Experimental instrument for this tensile test should have strong grip and highly stiff.

\section{MethOD}

Shear strength was conducted by ampere range variation of $80 \mathrm{~A}, 90 \mathrm{~A}$, and $100 \mathrm{~A}$. Materials used for this experiment is ST40 steel plate with ASTM E8 cutting standard [6]. It is $200 \mathrm{~mm}$ length, $50 \mathrm{~mm}$ wide, and $5 \mathrm{~mm}$ thickness. Welding process conducted on ampere range variation [7][8] of $80 \mathrm{~A}, 90 \mathrm{~A}$ and $100 \mathrm{~A}$. Shear strength conducted is using tensile test. Collected data is analyzed to achieve deduction of the test result.

\subsection{Research variable}

Variable is research object or the focus of research. Variable in this experiment is quantitative variable that has correlation to seam type and the use of ampere range of $80 \mathrm{~A}$, $90 \mathrm{~A}$ and $100 \mathrm{~A}$. Variables of experiment are dependent and independent variables. 


\subsubsection{Independent variable}

Independent variable is the influencing variable and it can be varied as the researcher needs [9]. In this experiment, independent variable used based on machine capacity is:

1. Ampere range 1 : five specimens are welded in 80 Ampere

2. Ampere range 2 : five specimens are welded in 90 Ampere

3. Ampere range 3 : five specimens are welded in 100 Ampere

\subsubsection{Dependent variable}

Dependent variable is variable with no change in this experiment, it is fixed [9]. Dependent variable in this study is shear strength on welding joint.

\subsection{Time and place of experiment}

This experiment was conducted in Metal Testing Laboratory Mechanical Engineering University of Muhammadiyah Malang.

\subsection{Material and equipment}

\subsubsection{Materials}

1. ST40 steel

2. RB26 electrode with $2,6 \mathrm{~mm}$ diameter

Tensile test specimen

Shape and size of object for tensile test based on ASTM E8/E8M standard

E8/E8M - 09

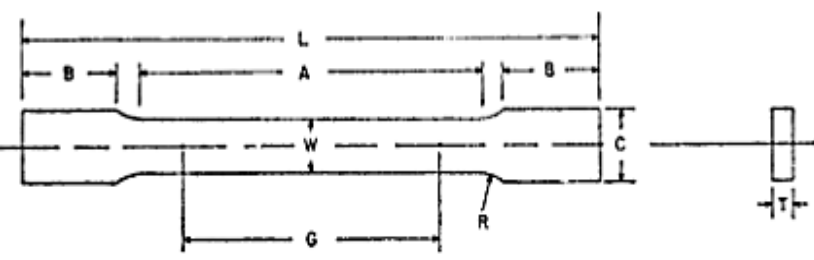

Figure 1. ASTM E8 Specimen standard

Table 2. Dimension of tensile test work-piece

\begin{tabular}{|c|c|c|c|}
\hline \multicolumn{4}{|c|}{ Dimensions } \\
\hline & \multicolumn{2}{|c|}{ Standard Specimens } & \multirow{2}{*}{$\begin{array}{c}\text { Subsize Specimen } \\
6 \mathrm{~mm} \\
{[0.250 \mathrm{in} \text {.] Wide }}\end{array}$} \\
\hline & $\begin{array}{l}\text { Plate-Type, } 40 \mathrm{~mm} \\
\text { [1.500 in.] Wide }\end{array}$ & $\begin{array}{c}\text { Sheet-Type, } 12.5 \mathrm{~mm} \\
{[0.500 \mathrm{in} .] \text { Wide }}\end{array}$ & \\
\hline & $\mathrm{mm}[\mathrm{n}]$. & $\mathrm{mm}$ [in.] & $\mathrm{mm}$ [in.] \\
\hline G-Gage length (Note 1 and Note 2) & $\begin{array}{c}200.0 \pm 0.2 \\
{[8.00 \pm 0.01]}\end{array}$ & $\begin{array}{c}50.0 \pm 0.1 \\
{[2000 \div 0.005]}\end{array}$ & $\begin{array}{c}25.0 \pm 0.1 \\
{[1000+0.003]}\end{array}$ \\
\hline W- Width (Note 3 and Note 4) & $40.0 \pm 2.0$ & $12.5 \pm 0.2$ & $6.0 \pm 0.1$ \\
\hline$T$-Thickness (Note 5) & {$[1.500 \pm 0.125,-0.250]$} & $\begin{array}{c}{[0.500 \pm 0.010]} \\
\text { thickness of material }\end{array}$ & {$[0.250 \pm 0.005]$} \\
\hline R-Radius of fillet, min (Note 6) & $25[1]$ & $12.5[0.500]$ & $6[0.250]$ \\
\hline$L$ - Overall length, min (Note 2, Note 7, and Note 8) & $450[18]$ & $200[8]$ & $100[4]$ \\
\hline A Length of reduced section, $\min$ & $225[9]$ & $57[2.25]$ & $32[1.25]$ \\
\hline B - Length of grip section, min (Note 9) & $75[3]$ & $50[2]$ & $30[1.25]$ \\
\hline C- Widih of grip section, approximate (Note 4 and Note 9) & $50[2]$ & $20[0.750]$ & $10[0.375]$ \\
\hline
\end{tabular}

\subsubsection{Equipment}

1. Electrical welding

2. Hand grinding

3. Hacksaw

4. Welding mask

5. Hammer slag

6. Steel brush
7. Handled hand files

8. Vice tool

9.Jangka sorong

10.Penggaris

11. Peralatan uji tarik 


\section{ResUlt AND Discussion}

\section{Research data}

Experiment materials

Length

: ST40 steel plate

Width

: $200 \mathrm{~mm}$

Thickness

: $50 \mathrm{~mm}$

Ampere range variation : 80A, 90A, 100A

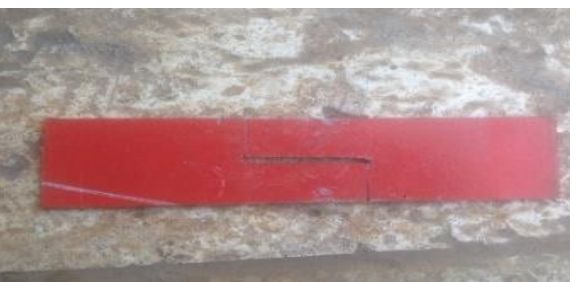

Figure 2. Work-piece

\section{Result of shear strength}

Experiment conducted in Metal Testing Laboratory Mechanical Engineering University of Muhammadiyah Malang results loading graphs of shear strength. Each specimen of shear strength conducted to obtain shear strength value.

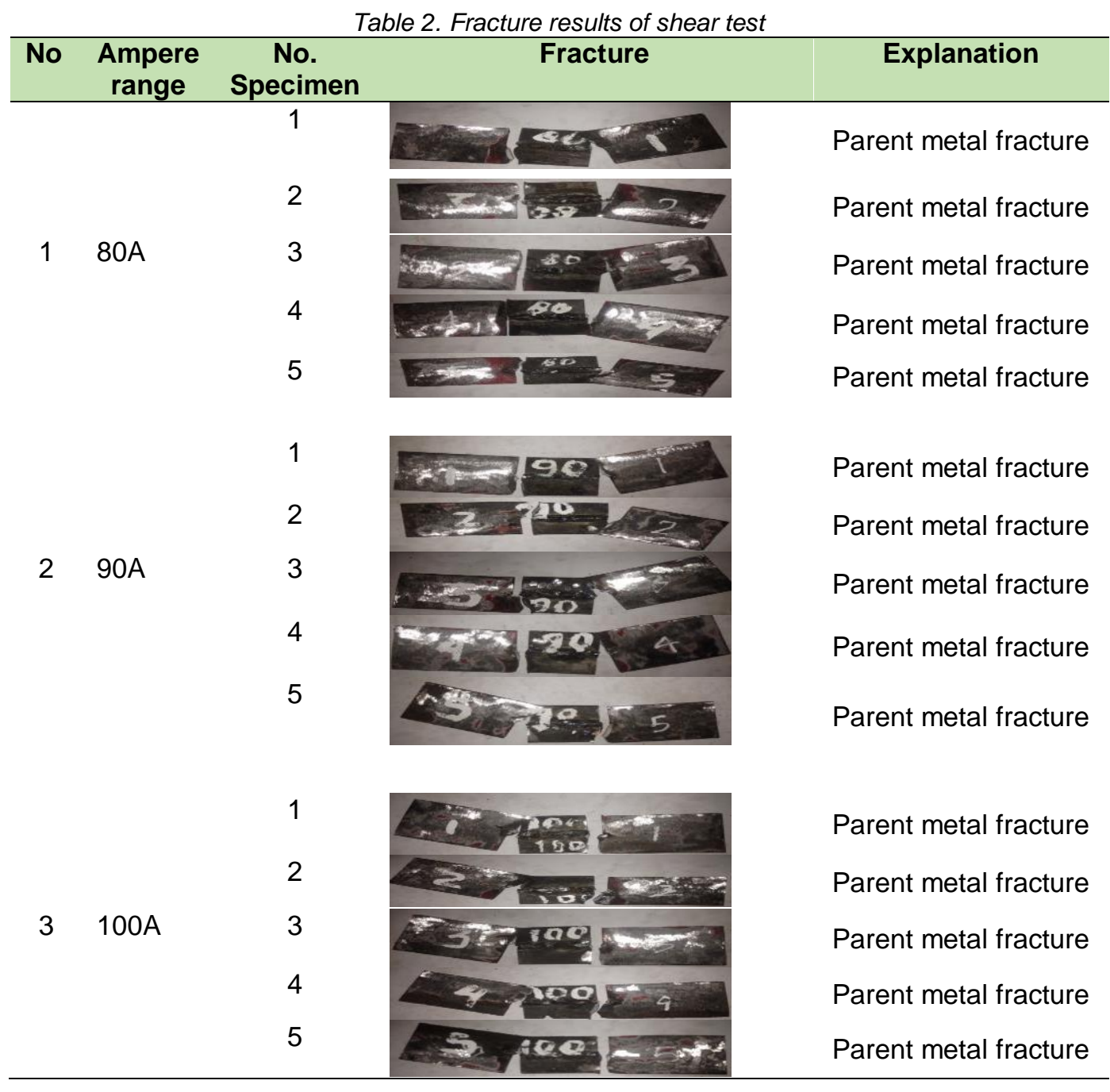




\section{Ampere}

Specimen 1

Plate thickness (t) : $5 \mathrm{~mm}$

Plate width (L) : $50 \mathrm{~mm}$

Welding width (I) $: 5 \mathrm{~mm}$

Welding length $(p) \quad: 50 \mathrm{~mm}$

Maximum loading (F) : $25.3282 \mathrm{KN} / \mathrm{mm}^{2}$

Fracture load $\quad: 17.6550 \mathrm{KN} / \mathrm{mm}^{2}$

a. Tensile stress

$$
\begin{aligned}
A \quad & =\text { thickness } \times \text { width } \\
& =5 \times 50 \\
& =250 \mathrm{~mm}^{2}
\end{aligned}
$$

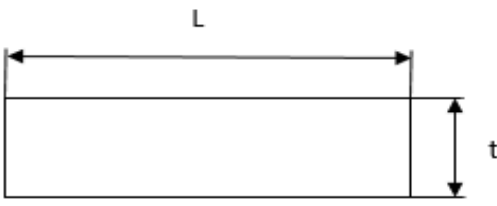

Figure 3. Plate cross-section

$$
\begin{aligned}
\sigma_{\mathrm{t}} & =\frac{F}{A} \\
\sigma_{\mathrm{t}} & =\frac{25.3282}{250} \\
& =0.1013128 \mathrm{KN} / \mathrm{mm}^{2} \\
& =101.3128 \mathrm{~N} / \mathrm{mm}^{2}
\end{aligned}
$$

b. Tensile stress and electrode shear stress

- Electrode tensile stress

$$
\text { } \sigma_{\text {electrode }}
$$$$
=60000 \mathrm{Psi}=413 \mathrm{~N} / \mathrm{mm}^{2}
$$

- Electrode shear stress

$$
\text { Ts }
$$

$$
\begin{aligned}
& =0.6 \times \text { electrode tensile stress } \\
& =0.6 \times 413=247.8 \mathrm{~N} / \mathrm{mm}^{2}
\end{aligned}
$$

Table 3. Result of shear strain

\begin{tabular}{ccccc}
\hline No & $\begin{array}{c}\text { Ampere } \\
\text { range }\end{array}$ & $\begin{array}{c}\text { Fracture load } \\
(\mathbf{K N})\end{array}$ & $\begin{array}{c}\mathbf{F} \text { max } \\
(\mathbf{k N})\end{array}$ & Ts= F/A (KN/mm) \\
\hline 1 & 80 & 17.655 & 25.3282 & 101.3128 \\
2 & 80 & 18.3602 & 31.0532 & 124.2128 \\
3 & 80 & 16.1528 & 26.3969 & 105.5876 \\
4 & 80 & 18.997 & 30.5134 & 122.0536 \\
5 & 80 & 19.6604 & 32.1129 & 128.4916 \\
Average & & & & 116.33168 \\
1 & 90 & 17.6916 & 24.8725 & 99.49 \\
2 & 90 & 19.1639 & 30.5356 & 122.1424 \\
3 & 90 & 19.6585 & 28.9852 & 115.9408 \\
4 & 90 & 18.2575 & 27.0535 & 108.214 \\
5 & 90 & 18.8675 & 31.1882 & 124.7528 \\
Average & & & & 114.108
\end{tabular}


Table 3. Result of shear strain (continued)

\begin{tabular}{cclcc} 
No & $\begin{array}{c}\text { Ampere } \\
\text { range }\end{array}$ & $\begin{array}{c}\text { Fracture load } \\
(\mathbf{K N})\end{array}$ & $\begin{array}{c}\mathbf{F} \text { max } \\
\mathbf{( k N )}\end{array}$ & Ts= F/A (KN/mm) \\
\hline 1 & 100 & 18.0751 & 30.0005 & 120.002 \\
2 & 100 & 19.3039 & 30.0131 & 120.052 \\
3 & 100 & 19.3125 & 27.4896 & 109.9584 \\
4 & 100 & 19.048 & 30.0371 & 120.1484 \\
5 & 100 & 17.2327 & 29.2879 & 117.1516 \\
Average & & & & 117.46248 \\
\hline
\end{tabular}

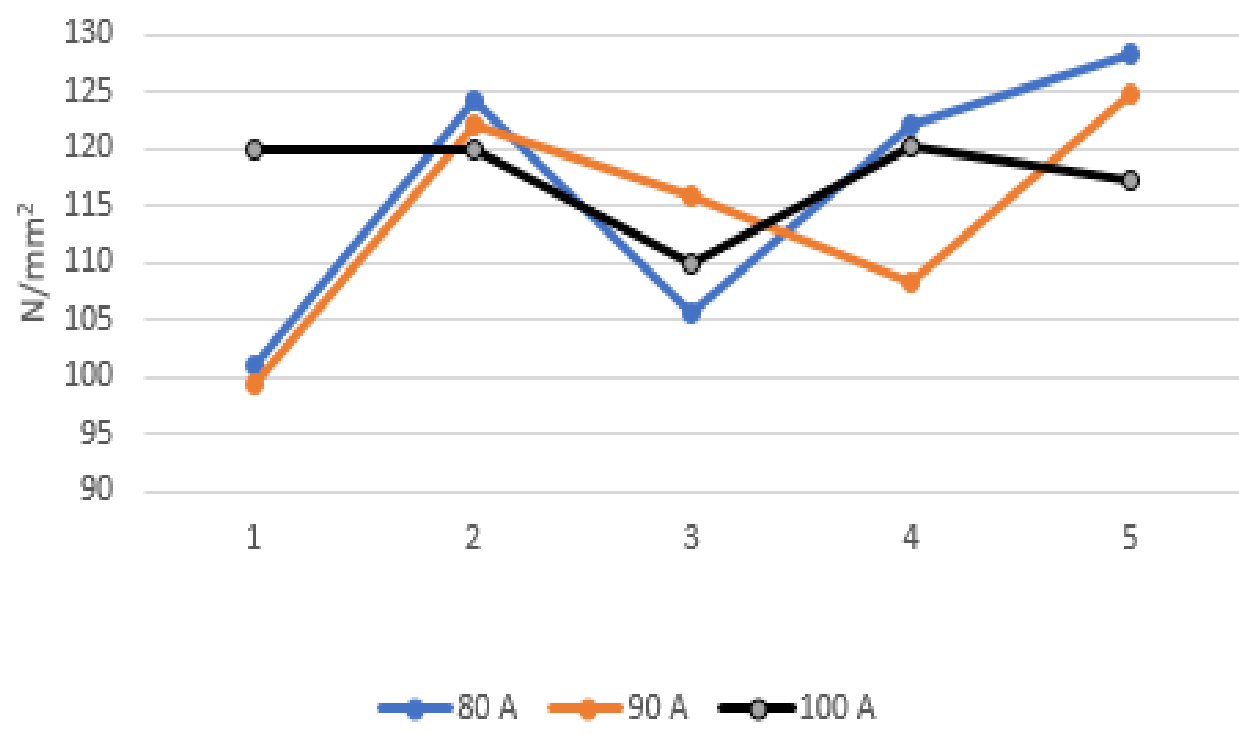

Graphic 1. Data of shear strength calculation

\section{Analysis on shear strength results}

- Result of shear stress shows that the highest value of $128.4916 \mathrm{~N} / \mathrm{mm}^{2}$ is on 80 ampere in specimen 5. Meanwhile, in 90 ampere range, the highest shear strength is 124.7528 $\mathrm{N} / \mathrm{mm}^{2}$ in specimen 5 . Moreover, 100 ampere range variation shows the highest value $120.1484 \mathrm{~N} / \mathrm{mm}^{2}$ in specimen 4 . The higher ampere range applied, the heat is higher. Pressure on electrode formed the welding joint. Yet, it is not always that increasing current will result better joint. There is a condition where the higher current will damage the welding result. It occurs because the melting point of each materials is different. If heat resulted exceeded the melting point of material, it would result the defecting welding joint.

- Fracture occurs in shear strength with tensile test is not damaging the welding joint but in parent metal. Shear strength with maximum load on 80 -ampere variation has tensile strength of $128.4916 \mathrm{~N} / \mathrm{mm}^{2}$. It is defected on parent metal. Meanwhile, maximum tensile strength on ST40 steel before treatment is $461.6 \mathrm{~N} / \mathrm{mm}^{2}$. With maximum tensile strength of $128.4916 \mathrm{~N} / \mathrm{mm}^{2}$, the specimen should not be fractured. As the tension is not exceeding maximum tensile stress of parent metal, the fracture occurs because of 
tension concentration on the tested specimen. Therefore, tension concentration triggered excess breakage and fracture on low load.

- Meanwhile, observed from tensile strength of welding electrode, its maximum value is $413 \mathrm{~N} / \mathrm{mm}^{2}$ and shear strength is $247.8 \mathrm{~N} / \mathrm{mm}^{2}$. The weld is not defected. It can be explained that maximum load on welding area is designed on the joint to have maximum shear strength of $128,4916 \mathrm{~N} / \mathrm{mm}^{2}$. This value is still smaller than shear strength of electrode material.

- As it is recognized, welded metal can be categorized into three; they are base metal (initial tested object). It is parent metal where heat and temperature of welding is not causing change on structure of metal characteristic. The second is Heat affected zone, it is basic metal adjacent to parent metal, which during welding process encounters heat thermal cycle and fast cooling that this area is being the most critical of welding joint. The third is Weld metal. It is the part of metal that in welding process, it melts and freezes up. Welding composition consists of parent metal and other materials from electrode. Fracture in welding area is the best fracture during shear strength because this area has high repetition heating.

\section{ConClusion}

From the result of testing, it can be concluded that ampere range variation has no correlation to shear strength of butt joint welding. What had been occurred in this test is pure tensile strength. Welding process is too long that when the specimen has tensile test, the parent metal is breakage or fractured.

Specimen is improved by adding radius and length of area. The seam is also improved to develop further research.

\section{REFERENCES}

[1] Ghazvinloo HR, Honarbakhsh-Raouf A, Shadfar N. Effect of arc voltage, welding current and welding speed on fatigue life, impact energy and bead penetration of AA6061 joints produced by robotic MIG welding. Indian J Sci Technol. 2010;

[2] Tewari SP, Gupta A, Prakash J. Effect of the Welding Parameters on the Weldability of Material. Int J Eng Sci Technol. 2010;

[3] Bodude MA, Momohjimoh I. Studies on Effects of Welding Parameters on the Mechanical Properties of Welded Low-Carbon Steel. J Miner Mater Charact Eng. 2015;

[4] Suhail M, Hasan MF, Bharti P. Effect of Welding Speed, Current and Voltage on Mechanical Properties of Underwater Welded Mild Steel Specimen ( C, Mn , Si ) with Insulated Electrode E6013. MIT Int J Mech Eng. 2014;

[5] American A, Standard N. Standard methods for mechanical testing of welds. Aws B4.0. 2007.

[6] ASTM (American Society for Testing and Materials). E8/E8M standard test methods for tension testing of metallic materials. Annual Book of ASTM Standards 4. 2010.

[7] Kim JW, na SJ. A Study on Prediction of Welding Current in Gas Metal arc Welding Part 2: Experimental Modelling of Relationship Between Welding Current and Tip-toWorkpiece Distance and its Application to Weld Seam Tracking System. Proceedings of the Institution of Mechanical Engineers, Part B: Journal of Engineering Manufacture. 1991.

[8] Kianersi D, Mostafaei A, Mohammadi J. Effect of welding current and time on the microstructure, mechanical characterizations, and fracture studies of resistance spot welding joints of AISI 316L austenitic stainless steel. Metall Mater Trans A Phys Metall Mater Sci. 2014;

[9] Kothari CR. Research Methodology: Methods and techniques, Second revised edition. New age international (P) Limited, Pubishers. 2012. 